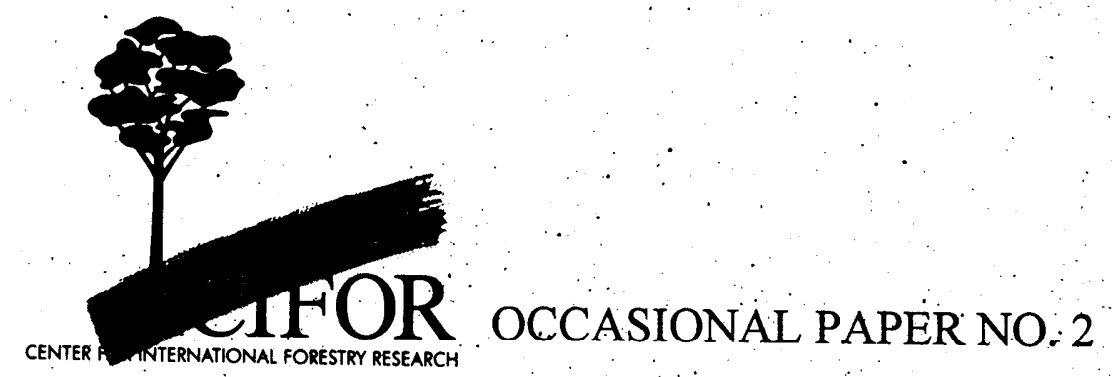

\title{
Social and Economical Aspects of-Miombo Woodland Management in Southern Africa: Options and Opportunities for Research
}

\author{
Peter A. Dewees
}

CENTER FOR INTERNATIONAL FORESTRY RESEARCH office address: Jalan Gunung Batu 5 Bogor 16001 Indonesia malling address: P.O. Box 6596, JKPWB Jakarta 10065 Indonesia tel.: +62 (251) 34-3652 fax: +62 (251) 32-6433

e-mail: cifor @cgnet.com 


\section{The CGIAR System}

The Consultative Group on International Agricultural Research (CGIAR) is an informal association of 41 public and private sector donors that supports a network of sixteen international agricultural research centers, CIFOR being the newest of these centers. The Group was established in 1971. The CGIAR centers are part of a global agricultural research system which endeavor to apply international scientific capacity to solution of the problems of the world's disadvantaged people.

\section{CIFOR}

CIFOR was established under the CGIAR system in response to global concerns about the social, environmental and economic consequences of loss and degradation of forests. It operates through a series of highly decentralized partnerships with key institutions and/or individuals throughout the developing and industrialized worlds. The nature and duration of these partnerships are determined by the specific research problems being addressed. This research agenda is under constant review and is subject to change as the partners recognize new opportunities and problems. 


\section{FOREWORD}

Why is one of CIFOR's first Occasional Papers about Miombo Woodlands?

The dry Miombo woodlands of southern and eastern Africa are very different from the tropical lowland rainforests that monopolize so much media attention. When the general public think about tropical deforestation - which they increasingly do - they think mainly of the Amazon, Borneo, and the Congo basin; tall pristine rainforests, teeming with rare wildlife, the material of so many calendars; being turned to barren wastelands by either large-scale industrial logging, or by shifting cultivation.

The Miombo Woodlands may not be so photogenic or so popular, and they are not threatened by large-scale industrial logging, but they are representative of a significant type of tropical forest ecosystem - dry woodlands occur in many tropical countries, e.g. India, eastern Indonesia, northern Australia, Central America, the cerrado in Brazil. But more importantly from CIPOR's viewpoint, there are very important processes at work in southern Africa, which are quite similar to processes occurring in other continents and in other forest types.

CIFOR undertakes generalisable, international, strategic research; CIFOR expressly does not undertake adaptive research to solve specific, localized forestry problems - there are National research institutions and development agencies which do this better than CIFOR. In many parts of the world, in many very different forest ecosystems, the processes leading to deforestation, degradation and fragmentation continue, not because of malevolence or neglect but primarily due to inappropriate policies which discourage conservative management of forests, or encourage other land uses at the expense of forests.

Many exciting new initiatives are already underway in this region, to explore mechanisms for local participation in forest management - "Resource Sharing". In some ways, this seems to parallel the renowned CAMPFIRE program developed in Zimbabwe for local management of wildlife, resources, and in some ways, the "User Group forest management" in Nepal and "Joint Forest Management" in India, for example. CIFOR is anxious to draw on the lessons of all these experiments and to assist in the dissemination of better policies and methodologies throughout the dry tropics.

CIFOR offers this Occasional Paper not only as a direct contribution to improved social, economic and institutional outcomes through sustainable forest management in southern and eastern Africa, but as an indirect contribution to those objectives throughout the tropical world, wherever similar policy issues arise. CIFOR would welcome comments from researchers, who recognize similar processes in their region, or who can contribute contrasting evidence and insights. 


\section{CONTENTS}

Background 1

Local management of miombo resources: an introduction $\quad 2$

What is management anyway? $\quad 2$

Participation and the commons $\quad 3$

Management for what? Benefits, private and public $\quad 4$

Looking at the long term 5

Common themes $\quad 5$

Institutional change, tenure, and access to woodland resources $\quad 6$

$\begin{array}{ll}\text { Resource sharing and state lands } & 7\end{array}$

Resource sharing and customary lands $\quad 7$

$\begin{array}{lc}\text { Considering local management } & 8\end{array}$

Economics of the household, and woodland use and management 9

The scope of household studies

Valuation $\quad 10$

$\begin{array}{ll}\text { Concerns about methodology } & 12\end{array}$

Woodland management for the market

High impact extractive industries

Small-scale forest or woodland based enterprises $\quad 15$

Directions for market research 16

Longer term social, economic and environmental changes 16

Policy, legislation and macroeconomic impacts on woodlands $\quad 19$

Impacts of forestry and natural resource policies and legislation $\quad 19$

Intersectoral policy linkages $\quad 20$

Agricultural and other land-use policies $\quad 20$

$\begin{array}{ll}\text { Structural adjustment and the environment } & 21\end{array}$

Are miombo woodlands valuable? For whom and for what? 22

Valuation ... again 22

Revising systems of national accounts $\quad 25$

Woodland conservation and management. Optimizing land use in the 25

drylands of southern Africa

Scope for research $\quad 25$

Woodland research options and opportunities: a summary 26

$\begin{array}{ll}\text { References } & 26\end{array}$ 


\title{
Social and E conomic Aspects of $M$ iombo W oodland M anagement in Southern Africa: 0 ptions and 0 pportunities for $R$ esearch
}

\author{
Peter A. Dewees ${ }^{2}$
}

\begin{abstract}
Summary
Five themes are identified for social, economic and policy research relating to miombo woodland management in southern Africa. They are: (I) patterns of local institutional change; (2) household use of woodland products; (3) markets for woodland products; (4) longer term dimensions to woodland use and exploitation and (5) policy and legislation. These themes are by no means definitive or exhaustive, but are described here as a means of focusing on the scope of future research, and as a basis for identifying priorities.
\end{abstract}

\section{Background}

This paper is being prepared for CIFOR as a discussion document. The intention is principally to identify and explore different areas for strategic research with regard to social and economic aspects of miombo woodland management in southern Africa. The existing body of research into the management of miombo woodlands has been principally ecological and silvicultural. Most research initiatives have failed to recognize the enormous pressures which are being placed on dry woodlands in southern Africa, and have not considered the underlying reasons for the extensive modification of remaining miombo woodlands as a result of human impact.

Even in the face of considerable resource constraints, miombo research continues to proliferate. Donors and national forestry research institutions are increasingly interested in this area of study. The capacity for undertaking social and economic research about miombo woodland management, however, remains limited, and most of these new projects continue to focus on how woodlands should be managed, rather than on why or by whom.

Strategic research in this paper should be construed to have regional dimensions to it, that is, we have chosen to focus on a number of common themes which have emerged across the region. These reflect both similar and divergent systems of land tenure, different types of markets for crops and tree products, contrasting rates of agricultural land clearance, as well as a range of climatic, edaphic, and geographic characteristics which have brought about the development of multiple land and labor-use strategies. Colonial and post-Independence land-use and forestry policies have similarly had a range of impacts on woodland cover. The common theme, of course, is how all of these factors relate to woodland management and use at the community and household level.

Social and economic research tends to make forestry researchers nervous. There has been a certain hesitance amongst national institutions to undertake this type of research. It is becoming increasingly clear, however, that the public sector simply hasn't the resources effectively to manage extensive woodland areas vis-a-vis the large human populations already dependent on them. In the face of burgeoning demands for agricultural land, and for woodland products, there is a growing recognition in southern Africa that individuals, local groups, and communities must be increasingly brought into the policy and planning process if woodlands are to remain productive resources for the next decades. A growing body of evidence strongly suggest that the only way of preventing the complete loss of

\footnotetext{
1 A discussion Paper prepared for the Center for International Forestry Research (CIFOR).

2 International Food Policy Research Institute, 1200 17th Street, Washington, DC 20036-3006, USA
} 
these woodlands is to empower local people to manage them, or to otherwise legitimize local management. Social and economic research is seen as a mechanism for informing the policy process in a way which can help to bring this about.

There are perceptual difficulties for many foresters when it comes to assessing the uses of miombo woodlands. The most economically productive miombo has been heavily modified by intensive use and bears little resemblance to 'woodland' per se. Thickets of heavily-coppiced miombo species hold little interest to those trained to think about "merchantable volume over bark.' Even so, these types of thickets are often a rich source of livestock browse, firewood, construction material, wild fruits and other foods. Conventional management research has simply not been designed to consider these multiple valuable products or production from heavily modified woodland thickets. Social and economic research can broaden the scope of silvicultural research more effectively to consider local utility and management.

These two concerns, then, help to define an agenda for social and economic research with regard to miombo woodlands.

- First, rural people are already heavily dependent on woodland resources to provide a range of benefits. Empowering local people or otherwise legitimizing existing local management practices is seen to be the most promising means of ensuring that woodlands continue to be productive into the future. The public sector however is poorly equipped to do this, and lacks the basic information needed to make sound policy decisions affecting institutional processes at the community level.

- Second, conventional silvicultural and ecological research has failed to address the management concerns of rural people. If control is to be devolved to communities or other local institutions, the impacts of policy and legislation on local management decisions must be better understood.

These are underlying themes which recur throughout this paper. This paper is organized into several sections. The section which follows gives a very quick overview of some of the principal issues which relate to local management of miombo resources. It focuses on a general research agenda, and how this might be shaped by several specific research areas. Subsequent sections of this paper explore and develop a number of different research themes.

Much of this paper is based on information collected from extensive interviews carried out during visits to institutions in southern Africa between 20 September and 8 October 1993 Much of the material discussed in this paper is, or has been, the subject of extensive review in the region (particularly in national policy reviews in Zimbabwe and Malawi), and I greatly hope I have captured some of the dimensions of the debate and discussion here. I was most appreciative of the courtesies extended during my visits, and have sought fairly to convey the views of researchers met. Nonetheless, errors of omission or interpretation are my own.

\section{Local management of miombo resources: an introduction}

\section{What is management anyway?}

There has been a tendency to suggest that woodland resources are generally left unmanaged. If the criteria of most conventional woodland management specialists were to be followed, this would probably be correct. We take a broader view, however, of what consists of 'management.' (See also FAO 1985). The most active forms of management of course involve adherence to a woodland management plan with fairly well-defined silvicultural objectives. Less active forms of management might involve the protection of naturally regenerating seedlings, rotational or selective harvesting of timber, grazing management, and so on.

In its broadest sense, the simple act of collecting wild fruit is a form of management, in that something of value has been extracted from a woodland area and the productive cycle has been disrupted from what it would otherwise have been. Whether wild fruit collection is part of an intentional woodland management regime is for the most part peripheral to the impacts of its extraction.

In terms of economic output, this type of management is far more productive than the type of management which relies on silvicultural prescription. The outcome is often that miombo woodlands become heavily modified in terms of species distribution, structure, and canopy cover, 
and bear little resemblance to the closed, undisturbed woodlands favored by foresters, wildlife experts, and conservationists.

\section{Participation and the commons}

Whether or not local people are able to manage woodland resources is dependent in part on rights of use and access. Land tenure is of central importance in this discussion. Most farming families in southern Africa live on land which is communally-owned or which is otherwise subject to customary controls. While home plots may be cultivated in a way which suggests de facto privatization, large areas of grazing lands (which are principally woodlands) remain under common control. The effectiveness of these controls, as well as conflicts between contemporary and customary land laws and institutions, are the subject of continuing research. In many instances, common controls fail effectively to function, and open access regimes more accurately characterize woodland management even though there may be a well established legal basis for common property management.

Woodlands in some areas are proving to be victims of the 'myth of the commons.' In the face of shrinking publicly-funded budgets for sectors which do not yield immediate financial and economic returns (such as for forestry and natural resource management institutions), governments are seeking to 'return' control over woodland resources to the communities most dependent on them. In many instances, there is a presupposition that earlier community controls over woodland use existed and were effective, when this may not have been the case. In other cases, governments may give customary authorities control over natural resources which far exceeds their capacity for management. In others still, it may mean transferring control over resources to a local elite who may use woodlands principally for immediate political or economic gain.

Finding equitable mechanisms for devolving natural resource management through processes of local institutional change should become a central feature of woodland management research. Such research should consider issues with regard to land and tree tenure, rights of use and access, gender issues, as well as 'resource sharing' initiatives which seek to grant rural people rights of use and access to state-owned forest lands.
Perhaps surprisingly, this type of research has received relatively little priority. In the absence of a better understanding of how institutional processes work, and how policy and legislation can be better framed to encourage these processes, it will be a considerable challenge for many rural communities with devolved natural resource management responsibilities to meet the high expectations of governments and donors, which have been partly engendered by the new rhetoric of 'local participatory management.'

Indeed, there is a need for a more substantive view of human impacts on woodlands, the place of local institutions in woodland management, and the potential for truly participatory management. A study of local environmental management in Guinea suggested

The social theories underlying modern 'participatory' approaches not only assume that pre-colonial local resource management systems were once effective 'in their own terms, but also by leaving begging the question of what those terms might be - assume old local priorities to be identical to those of modern environmental projects... They assume that local land use is inevitably degrading, that more people means more degradation, and that resource use can be rendered sustainable only by improving forms of 'regulation', 'authority', and 'organization.'

(Fairhead and Leach 1993b, p.32)

They concluded that local priorities are based in encouraging and maintaining balances between a diversity of vegetation types and that

effective long-term resource management depends less on community-level authorities than on the cumulative effects of multiple, seasonallyand socially-sequenced actions by individuals and small groups, oflen over long periods, and the ways that the maintenance of productivity is built into production patterns.

In contrast, common property management regimes are characterized by the right of a group to exclude others outside of the group from using a resource. This may include mechanisms and penalties for ensuring compliance to rules agreed upon by the group. Fairhead and Leach argue that effective environmental management in Guinea is far less proactive, and dependent more on individual action rather than on the actions of a larger community. 
Nonetheless, some form of more responsible management over natural resources, with enforceable mechanisms for control over access and use, must surely be preferable to past systems of management. Concession policies and forest legislation in earlier periods led to the widespread degradation of large areas of miombo woodlands throughout southern Afica to meet the demands of mining and timber interests.

\section{Management for what? Benefits, private and public}

Woodlands in southern Africa produce benefits for farmers living on customary or communal lands which fall into four categories:

- Foods, such as fruit from indigenous woodland trees; other wild foods collected from woodlands, such as mushrooms and edible insects; habitat for small-scale food production, such as honey.

- Soil nutrient inputs through nutrient cycling and through nitrogen fixation. Environmental services, such as protection from soil erosion are also provided.

- Fodder and browse for goats and cattle; and

- Construction timber, firewood, and other material for either domestic consumption or for local sale.

Many of these benefits are also available to urban dwellers through the marketplace. Particularly in resource-constrained economies, when farming households balance the benefits from different land-uses (which might involve tree or woodland management), they consider only private benefits, such as those described above. Individual households seldom perceive the immediate value of public benefits (local, regional, or global) to their own farming system, and so these have little impact on most household decision-making processes. Public benefits are of greater relevance to the community, but even so, seldom figure significantly in defining strategies for woodland management.

Woodland and tree benefits more generally comprise a range of direct and indirect private and public benefits, including

direct, local private benefits, such as foods and fuelwood, which are valued principally for consumptive purposes; indirect, local private benefits, such as soil nutrient inputs or livestock fodder and browse, which are extracted and used for some particular aspect of the farming system rather than for household consumption;

indirect, regional semi-public benefits, resulting from soil retention, streamflow regulation, and recreation; and

indirect, global public benefits, from carbon sequestration and the preservation of biodiversity (Bojö, 1992).

The focus of much of this discussion is on the impact of private benefits on local management decisions. These private benefits principally affect decision making amongst households and groups of households with common rights to woodland resources. With few exceptions, there has been very little work carried out on the extent of household or communitybased woodland management strategies in southern Africa. For policy and planning purposes, an understanding of where, how, and why households have used woodlands and woodland products in their productive strategies is essential. Valuation studies and research into household allocation processes are all critical for developing this understanding.

A closely related set of research themes has to do with the operation of markets for products from woodlands. These markets are quite different from markets for agricultural commodities because of the limited range of policy instruments which can be used to influence how they operate. Agricultural commodity markets, in contrast, can be manipulated by pricing policies, subsidies, credit regimes, input supply, labor legislation, and so on. Arguably, many of these policies are geared toward increasing the supply of agricultural commodities. Policies toward forest products, however, are typically geared toward limiting supplies. Control regimes, licensing, traffic checkpoints, roadblocks and increased royalty collection from users of woodland products have all featured prominently in the approaches undertaken by governments to limit woodland exploitation.

These approaches are largely based on the assumption that the commercial harvesting of woodland products damages woodlands. While this is certainly true for particular types of extractive processes (such as woodland clearance 
to meet the demands of woodfuel markets), the harvesting of many extractive products poses little threat.

Local management of woodland resources would be more promising if markets operated in a way which encouraged (rather than discouraged) their sustainable use. Forest-based enterprises have been shown to be particularly important primary enterprises for many households. Strategic research should be developed which focuses on the nature and operation of woodland product markets, smallscale forest or woodland-based enterprises, and how financial benefits from woodland management can accrue to woodland managers.

\section{Looking at the long term}

We have argued that much miombo woodland in southern Africa has been heavily modified by intensive use. Longer term studies of land-use change in southern Africa have suggested that, even amongst the most intact of woodlands, there is very little unmodified miombo anywhere. In Malawi, for instance, heavily modified miombo accounts for over 95 percent of existing woodland, cover (Hardcastle 1993). Mature miombo woodland in the Tabora region of Tanzania is mostly regenerated. Lawton (1982) reports that the area was well cultivated in the $1860 \mathrm{~s}$. The area was later evacuated due to an outbreak of sleeping sickness in the early 1900s. Formerly cultivated areas of Zimbabwe, depopulated during the early 19th century because of the Ngoni invasions, eventually regenerated into extensive areas of miombo (Lawton 1982). There are few studies of these significant land-use changes, and in most miombo literature, they only bear passing mention.

Among the more profound impacts on woodland cover in southern Africa were the result of Colonial natural resource legislation as well as land-use planning and administration interventions. Most legislation reflected the prevailing view that African areas had to be heavily regulated, while voluntary controls were encouraged in European farming areas. Land use planning initiatives were largely coercive, for instance, involving the consolidation of villages in 'lines', and the delineation of grazing and arable areas on the basis of calculated carrying capacity.

Land-use planning initiatives and natural resource legislation had significant impacts on woodland cover. While the assumption is often made that these approaches have been abandoned, they continue to shape and influence patterns of land and resource use and policies and legislation throughout the region. Because of this, research into the local management of woodland areas must consider longer term dimensions of land-use change reflecting the historical development of legislation and policies vis-a-vis the pre-colonial, colonial, and independent periods.

Demands for agricultural land have been and will likely continue to be the most significant factor influencing the extent to which woodlands are managed in ways which contribute to the stability of farming systems. Planning for agricultural expansion must then have the dual objectives of increasing the area under cultivation in a way which reflects the critical role of woodlands in farming systems. The transformation of woodlands must be guided by the rate at which productivity in newly cultivated areas can be maintained, rather than by a simple desire to expand the area under cultivation. Agricultural productivity in newly cleared areas of woodland is likely to fall precipitously unless either large areas of woodlands are retained which can provide a range of low-cost inputs into farming systems, or unless capital intensive fertility inputs, fuel supplies, fodder resources, and food are otherwise provided.

\section{Common themes}

In summary, then, there are a number of common themes which have influenced and shaped locallevel miombo woodland management and use throughout southern Africa. These include:

1. Patterns of local institutional change. Land and tree tenure. Rights of use and access to woodlands. Gender issues. Resource sharing. Research must be geared toward finding equitable means of devolving responsibility for natural resources to local institutions, either by strengthening existing locally-based management or by otherwise creating the means for local management.

2. Household use of woodland products. Role of woodland and tree products in household production strategies. Risk and decision making processes. Differentiation and woodland use. Valuation.

3. Markets for woodland products. Function and operation of small, woodland-based industries. Employment characteristic. Sources of supply. Impacts of policy and legislation. 
4.Longer term dimensions to woodland use and exploitation. Earlier natural resource and landuse legislation and policies. More recent impacts of these policies on existing practices at regional and local levels. Political processes and rural communities.

5. Policy and legislation. Impacts of, contemporary policies and legislation on woodland use and management. Consideration of broader land-use policies, rather than forestry policies alone: structural adjustment, crop input pricing policies, access to credit, agricultural policies, etc. Subsequent sections of this paper focus on each of these themes in turn, seeking to clarify and expand upon the existing body of research.

\section{Institutional change, tenure, and access to woodland resources}

Concern about miombo woodland management is partly rooted in the growing perception of the importance of these areas to rural households and communities. Because of their high degree of dependence on miombo areas, there is an increasingly widespread view that their long term conservation and management can only be assured if communities are brought more actively into the management process, and if rights of use and access are assured through legislative and policy reform.

Easier said than done. Land tenure over wooded areas may be held by the state, which has a particularly strong interest in maintaining its long term rights to state lands such as national parks and reserves. It may be held by commercial farmers or by an estate sector with little interest in woodland management or conservation and who see any discussion about devolution of control over woodland areas as a threat to expropriate their land. Local councils usually have responsibility for the administration of customary lands, and have the right to allocate land for agriculture. In the face of growing land pressures, councils see little incentive to maintain land under wooded cover. If we speak purely from the perspective of tenure over land, there are indeed considerable institutional obstacles to devolving control over woodland areas to local communities.

If we speak instead of tenure over trees (the right to harvest, use, or sell woodland products) the dimensions of the argument are only slightly altered. The state typically has had the most dealings with timber and wildlife interests in terms of assigning the right to use woodland products from state lands to institutions other than itself. While there are sometimes arrangements made which allow people living in peripheral areas around state lands to engage in the nondestructive extraction of woodland resources, it is far less common to find these arrangements so extensive as to allow commercial exploitation. Similarly, large scale commercial farmers more commonly seek to exclude anyone who represents a threat to their long term rights as landowners and see the collection of woodland products from their land as 'poaching'. Finally, councils often retain rights to revenues from woodland exploitation on customary lands, even if trees are found growing on land which has been allocated to a household. Much forest legislation in southern Africa greatly restricts the rights of households to benefit from woodland management for anything other than for subsistence use. ${ }^{1}$

In some instances, the state (rather than local councils) has maintained that it has the rights to revenues from any trees growing on any land. This has resulted in the creation of large and expensive bureaucracies devoted to licensing, revenue collection, and regulation. Resource constraints prevent these bureaucracies from operating effectively. Even if they were able effectively to do their job, it would drive the market underground, and reduce any interests which communities might have in long-term sustainable woodland management. Where a national forestry institution has regulatory responsibilities as well as responsibilities for rural forestry extension, obvious conflicts are likely to arise.

It has been widely argued that, at the local level, customary controls over woodlands have the greatest potential for being the most effective. In some areas, this is most certainly the case. Wilson (1990), McGregor (199 1), Scoones and Wilson (1989), Fortmann and Nhira (1992), Coote et al. 1993b) and others have documented extensive examples of where

${ }^{1}$ There are some encouraging changes however. In Malawi, for instance, pending forestry legislation would guarantee anyone who plants or protects a tree the rights to benefits from its management. 
ustomary controls have been effective at limiting woodland damage and at conserving and managing miombo areas. Still, these examples also show how difficult it is to implement these types of control systems in situations where customary authorities are weak, where they are in conflict with other communities or with new local institutions, or where long term patterns of settlement have been disrupted by in-migrants and new settlement.

The new rhetoric of participation, which argues for a devolution of natural resource management responsibility to the local level, presupposes community controls can be effective in the first place. Even so, there are few examples where devolution has had such a straightforward impact. In southern Africa, the greatest experience with these types of initiatives has been in the implementation of wildlife or livestock management programs.

There are very few examples where government has sought unambiguously to devolve control over a woodland area to a community in southern Africa with the objective of improving its management. Even fewer studies have sought to evaluate the benefits to households and communities of doing $\mathrm{so}^{2}$. This is partly because there is such a large range of potential benefits and beneficiaries, and because there are few clear mechanisms for control and accountability over revenues from woodland management.

The clearest conflicts over the right to use woodland resources have arisen when different user groups have placed claims on woodlands or on the land on which they are found. The most obvious conflicts are found between governments and the people living in, or adjacent to, stateowned woodlands. They are also found between long-term residents and more recent settlers, between households in customary lands and local councils, and between residents of different communities dependent on the same resource. 'Resource sharing' is the term which is increasingly being used to describe the resolution of these conflicts by developing management strategies where all user groups can benefit.

\section{Resource sharing and state lands}

Forest reserves and national parks are almost

2 In contrast, programs like Zimbabwe's CAMPFIRE have been carefully evaluated to determine their financial impact at the household level. universally places where local people attempt to exercise rights of use, despite the state's statutory claim to the land and the trees. Throughout southern Africa, the situation is no different. State forests are often surrounded by heavily settled areas, and conflicts usually arise between the state and local people who have encroached into the woodlands for a variety of reasons, such as for hunting, the unlicensed grazing of cattle, wood collection, and the clearance of trees for cultivation. Arrangements which allowed certain users temporary rights of tenure to these woodlands have created longer term problems for subsequent generations. Forest departments, in the best of all possible worlds, would like to retain their exclusive right to use their land as they see fit, while people from surrounding areas would like to see woodlands cleared to allow settlement.

There are really two types of conflicts which need separate (but not mutually exclusive) responses. The first has to do with the problem of settlement on state lands, while the second has to do with the use of resources within state lands by people living on their periphery. A failure to identify effective solutions which are specific to these two types of conflicts (and indeed, which are far more specific to the conditions of tenure, settlement, and land-use which characterize each particular conflict) has posed significant problems for national forest departments.

Forced evictions and the criminalization of people who use resources collected from state lands has characterized the response of the state to many of these conflicts. In many respects, these confrontational approaches have increased local political support for the redistribution of state lands. Governments have found themselves in an increasingly defensive position over the assertion of their statutory right to use and manage their own lands. The articulation of a cogent set of objectives for the use of state lands, in a way which reflects broader economic and policy considerations, has been problematic, and governments refuse to abandon their exclusionary focus on the protection of woodland areas as watersheds and as natural habitats. There is little question that any significant shift from this view will entail possibly high costs for national forestry institutions.

\section{Resource sharing and customary lands}

Much discussion about the breakdown of customary systems of resource management accepts the assumption that common property 
management systems are being increasingly replaced by open access exploitation, which is followed by a deterioration in the resource base. This section focuses on the potential for common property systems of woodland management in customary lands. At the crux of the issue is the question of how and by whom rights of control and access are defined. Strengthened systems of common property management depend on communities holding greater control over woodland resources.

There are real constraints to giving communities or individuals control over the management of woodland resources. These constraints are ftrmly rooted in legislation, land usage rules, and other practices and policies. Much legislation is fundamentally restrictive, rather than enabling. While legislation may recognize the rights of people living in customary lands to use woodland products, they are usually not allowed to use products which someone else has been licensed to exploit, to use 'reserved' trees except by license or permit, or to sell anything collected from woodland areas. These types of restrictions were basically designed to strengthen the rights of concessionaires to commercial timber species, and of local councils to revenues from them.

Strategies for resource sharing in customary lands must focus on finding ways for the benefits of woodland use to be returned to the communities responsible for their management. This applies to the exploitation of commercial timber species, as well as to the range of other woodland benefits on which households are dependent. Effective common property management regimes have been characterized by,

- the lack of exclusive, individually-held rights of use or access;

- communally-defined guidelines for resource use;

- an enforcement mechanisms for punishing those who violate community guidelines;

- mechanisms for clearly defining communal group membership; and by

- $\quad$ secure expectations amongst group members that they will continue to have access to commonly held resources in the future (Arnold and Stewart 1991).

Common property regimes sit comfortably with the idea that develonment should be local, democratic and participatory. Because much customary land in southern Africa is held communally (at least in theory) the idea that common property regimes can be used to manage communally-held woodlands has much appeal. This is particularly so for development practitioners for whom 'participatory' development is in vogue.

Are common property regimes the solution to the problem of woodland management? Not unequivocally. Far less active strategies may be more effective, particularly in areas of longsettlement (cf. Fairhead and Leach 1993a, 1993b). Experience has increasingly shown that it is usually very difficult to bring about the conditions for effective common property management. Research which has the objective of informing the policy process must necessarily take a broad view about the variables which influence patterns of woodland management.

\section{Considering local management}

These various dimensions of local land management emphasize the need for better information about institutional processes and how they interact to affect rights of use and access to miombo woodland areas. Finding equitable mechanisms for devolving natural resource management through processes of local institutional change should become a central feature of woodland management research. In this regard, there are five closely related areas of research (adapted fro Scoones and Matose 1993):

Planning processes and structure. What mechanisms are there for developing viable and locally-derived plans for management? How can planning processes ensure flexibility in management approach, diverging from the rigid technical prescriptions of past approaches? How can management planning be made responsive to the range of demands which households place on woodlands

Governance and local level resource management. What local level institutions would be best placed for implementing management plans? How can adequate representation in these institutions be ensured? What role does the state have (particularly, the extension services) in 
supporting local level management? What steps would be needed for the state to transfer governance responsibilities to the local level? Is there any support within government for this approach? What alternatives to decentralization are possible?

- Institutional capacity for resource management. What planning, fmancial, and legal requirements must be met to enable local institutions to adopt management responsibilities? Are local institutions technically able to introduce woodland management? How can accountability be built-in to the process of institutional change?

- Land and tenure. Who has rights of use and access to woodland resources? How do patterns of use and access differ by gender? How would devolved control over woodlands alter current patterns of land and tree tenure? What would be the genderrelated implications for devolved management? What would be the likely outcome in the absence of changes in tenure? What risks would the state and private landowners have in allowing people the right more intensively to use woodland resources from state and private lands?

- Rural investment. How can woodland management initiatives be linked with investments in resource conservation? What options are there for investing directly in woodland management, or in other sectors which would increase the incentive to conserve and manage woodlands (livestock or wildlife management, irrigation, timber production, small-enterprise development)?

\section{Economics of the household, and woodland use and management}

\section{The scope of household studies}

It is suggested above that rural households gain four principal types of benefits by relying on woodlands: foods, soil nutrient inputs, fodder and browse for livestock, and wood products (such as construction wood, ftrewood, and so on). Benefits accrue to these households principally because of interactions between sectors, for example, because woodlands provide dry season browse for cattle, which in turn provide manure and draught animal power for crop production. While there is a growing body of information about these types of benefits and interactions between sectors, their impact at the household level is very poorly understood.

Precisely how tree resources are used (and are able to be used) ultimately determines their impact on household productivity. Direct benefits (woodfuels, wild foods, construction timber and so on) feature importantly in meeting subsistence household demands. Direct woodland benefits can also be bought and sold, generating badly-needed income, the lack of which has in some areas limited access to food crops which households may be otherwise unable to produce.

Indirect benefits (the use of woodlands as a grazing resource, leaf litter transferred from woodlands to fields, and so on) are also considerable and there are few viable substitutes to be found in the market. Partly because of this, and because of limited purchasing power throughout much of rural southern Africa, indirect benefits feature even more prominently in household subsistence production strategies, and are less commonly bought and sold.

Some studies have suggested important differential impacts of woodland use. Wilson (1990), Scoones (1990) and McGregor (1991), in their studies which considered woodland use by communal area households in Zimbabwe, all strongly indicated that poorer households are often much more heavily dependent on woodlands and on trees for food, soil nutrient inputs, income, and so on.

There is, of course, a strong association between rural poverty and food security. Household food production can be constrained by small plot sizes, poor quality soils, and low rainfall. The problem of poverty is worsened by the lack of access to credit and problems of labor supply. The burden of farm labor is provided by women. An increased workload on women is symptomatic of labor constraints, and both compromises the nutritional status of women and predisposes newborn children to malnutrition (Tagwireyi 1990).

Some research suggests that problems of food security are distinct problems of poverty. Jackson and Collier (1988) showed in Zimbabwe that low-income households with a range of income sources were less prone to collapse into acute hunger than low-income households with limited access to assets and with a narrower range of income sources. Risk spreading in this way reduces household 
exposure to the impacts of drought. The capability to spread risk is perhaps greatest amongst those households which are able to exploit resources in a range of microenvironments, such as in patchy woodland areas (Wilson 1991, Scoones 1989).

Especially with regard to the use of woodland resources, risk spreading is partly a function of the seasonality of access and use. Particularly during the late dry season, and before the harvest, woodlands can provide rural households with critical and badly needed inputs. Woodland resources may be viewed as assets which can be used during difficult times, as a means of diversifying crop production and income (from the sale of woodland products), and as buffer stocks of food, browse, and fodder during times of drought.

The differential impacts of woodland use at the household level in terms of risk spreading, poverty, and food security are poorly understood. Tree resources play an unclear role in household allocative processes in terms of affecting patterns of labor use and employment, land use, and income and expenditure. Most studies about tree and woodland use in souther Africa (outside of the commercial sector) which could be construed to have an 'economic' content are fundamentally lacking in analysis. Generally, they consist of extensive tables of descriptive statistics which emphasize only that rural people use and manage trees. They seldom explore causal factors, and there are few studies which seek to link broader patterns of agricultural production and household economics with tree-related land-use choices. Nor do these types of studies address the differential impact of the use of woodlands across groups of households.

If meaningful analyses of trees and woodland resources are to be undertaken, they must necessarily focus on the household and the community, for example, not that a certain percentage of households are dependent on these resources, but which households, when, and under what conditions.

As we have suggested, household differentiation and a dependence on woodland resources are closely linked. This has important implications for who undertakes woodland management and how they are to be managed. For example, there is some evidence which suggests that poorer households are more dependent on wild fruits than better off households. Seasonal access to wild fruits is important, and has been shown to reduce malnutrition rates among small children. The extent to which fruit trees are planted is linked to the extent to which wild fruit trees have been left in fields, and this is in turn linked to the species composition of woodlands which were cleared prior to cultivation (Wilson 1990).

Household studies, then, must firstly consider the extent of dependence on woodland resources. A number of baseline surveys have taken this approach (see, for instance, du Toit rt al. 1984). As we have suggested, more substantive economic studies are needed which consider

the impacts of woodland access and use across groups of households in different income groups,

the role of woodlands in diversifying household access to inputs into the farming system and its relationship to risk,

linkages between household differentiation, the diversification of inputs to farming systems, and seasonality of dependence on woodland resources,

the association between food security and a dependence on woodland resources, ' and

- the balance between subsistence and market demands for woodland products.

All of these elements suggest the need for an approach which considers a great diversity of factors affecting farming households.

\section{Valuation}

The need for better 'valuation' of woodlands and their products has been a recurrent theme in much of the literature about miombo use and management in southern Africa. There are different audiences for these types of studies, and these are discussed in greater detail in Section 7.3 of this paper.

Environmental values can be derived in part by looking at three particular markets: conventional markets, artificial markets, and implicit markets. Conventional markets reflect the real or replacement value of a product (or of a 
service) which is the next-best option. ${ }^{3}$ Artificial markets can be constructed using techniques such as contingent evaluation to determine consumer preferences for woodland products. Finally, woodland values are also thought to be reflected implicitly in markets for land where these operate without distortion ${ }^{4}$.

At the household level, valuation, derived from consumers own preferences, is of some interest because it should (in theory at least) tell us what woodlands are worth, based on the consumers 'willingness to pay'. A key constraint, however, is that most methods of valuation rely on imputing values for specific woodlands products rather than for the woodlands themselves. Campbell et al. (1991) for instance, calculated farm-gate values of specific woodland products on the basis of household use per year. Willingness-to-pay, assessed through a contingent valuation exercise in the same study, also considered the value of woodland products per household.

Four particular variables must be considered in establishing the value of benefits from woodlands: the number of households who can exploit them, the density of woodland cover, species diversity and woodland productivity, and

\footnotetext{
${ }^{3}$ Such as the farm-gate price of wild fruit, or the replacement value of leaf litter in terms of the nitrogen available in an equivalent amount of chemical fertilizer, or the value of labor spent collecting a particular amount of firewood -when these represent the next best option for households in the absence of wild fruit, leaf litter, or firewood. In practice, there are often less costly options open to the household, which may involve conservation.

${ }^{4}$ There are substantial market imperfections with regard to woodland use throughout southern Africa, which make market values insufficient as a guide to social choice. Arguably, the state does not usually consider market values in its land-use decisions, woodlands held by the state are not traded in any market. Markets for woodlands held by the estate or commercial farming sectors are distorted in part by long-standing inequities in access to capital, and by land-use policies restricting subdivision and sale. In most other rural areas, land ownership is vested in the state, and land administration is the responsibility of local councils or authorities which operate without consideration of market values. Because of these types of imperfections, implicit markets offer little guidance for establishing the real economic value of woodlands.
}

(if farm-gate prices are to be used) the presence of some markets where woodland benefits could be bought and sold. The first two of these can be considered jointly, and evaluated in terms of woodland canopy cover per person or "woodland dependency.' Studies which have taken this approach have shown large differences in rates of woodland dependency, suggesting that woodlands would have to be valued quite differently from area to area (Bradley 1990).

Evaluating the impact of species diversity and productivity on woodland value is even more problematic. Miombo woodlands, for instance, have a much greater diversity than many other woodland types. Fruit trees are as much as 4 times more abundant in these areas than in mopane woodlands (Campbell 1987). While the total value of products which could be derived from a fixed area of miombo woodland could be quite high compared to mopane woodland, the marginal utility of additional production could be quite low simply because of the relative productivity of these woodlands. In contrast, while the total value of products derived from a fixed area of mopane woodland could be quite low, the marginal utility of additional production could be quite high, particularly if there are large populations dependent on limited resources. Most valuation studies have not considered the marginal value of production 6 .

There is no generalizable model about how much woodland is needed to produce what households consume. This will vary depending on the benefit under consideration, and whether or not production is from clearfelling or from the

5 Fisk (1975) argues that it is impossible to impute a price for a commodity that a farmer produces or uses to meet family needs without even considering exchanging it at the market. $\mathrm{He}$ suggests that in these types of studies, a complete separation of subsistence and monetary production is needed and that non-marketable household goods and services as well as market goods would have to have a common nonmonetary utility index.

${ }^{6}$ Campbell et al for instance, valued wild fruit quite highly but only because it was assumed that all wild fruits from woodland areas are consumed and are valued at prevailing market prices. Using a more 'conventional marginal utility approach, the value of wild fruit is likely to be considerably less -- a point acknowledged by Campbell et al. 
harvesting of yields. The large range of variables affecting woodland production and use makes it difficult to infer much about the "value of woodlands' and empirically sound woodland valuation still eludes most researchers.

The desire to focus on this approach is partly rooted in the assumption that individual or household values can be aggregated in a way which should guide social choice. As we have suggested, methodological limitations currently prevent economic or policy analysts from doing so in a way which is empirically rigorous.

This is not to say that valuation research should be discarded altogether, but rather to suggest that it must be more carefully focused at the household, and at the relationship between imputed values for woodland products and the household economy. This line of research could be a tremendously fruitful one, as it could help to clarify the tradeoffs between woodland management and other household resource allocation strategies.

\section{Concerns about methodology}

Particularly amongst researchers in fields other than economics, there is a concern that the need for statistical validity in analyzing data from household studies and surveys obscures larger and more fundamental issues which are seldom captured in household survey work. While this is an increasing concern of researchers more generally, there is special relevance for household research about natural resource use and management because of the large number of variables which influence household decision making about resource and woodland use.

The problems of large surveys and sample sizes, the overcollection of data, and burdensome survey instruments are well known. At the other extreme, there is a concern that more interactive 'rapid appraisal' types of research approaches seldom provide adequate information for informed policy making in a way which is intellectually rigorous. There is clearly much truth in both of these views.

A view which is gaining increasing currency is that neither of these approaches should be a substitute for the other. Rapid appraisal can be extremely useful for focusing research on critical issues, which can be further developed in a way which is intellectually rigorous in household survey work. There is a very real need to focus more critically in household survey work, and rapid appraisal can be a very useful tool in doing this.

The concern is somehow that something will be missed. Researchers argue that the marginal costs of additional information collected in survey work is low, and that a failure to ask sufficient questions in survey work will result in critical oversights during analysis. Statistical validity is another concern.

The development of proxies in survey work for different indicators is a useful direction. Household composition and the structure of labor supply, for instance, can be a useful substitute for intensive time studies. Simply because of the degree of variation across households, qualitative indicators can sometimes provide a better picture of how households are making resource allocation decisions.

There are statistical and econometric tools for dealing with qualitative indicators. The analysis of decision-making, reflected in dichotomous variables for instance, is possible with different types of regression analysis. This allows the analyst to model binary choices (rich or poor, labor constrained or not, woodland scarce or not, and so on) from a set of discrete variables. The most difficult task for the analyst is deciding what minimum data set will be necessary and sufficient for addressing the questions posed. Economic research needs to be much more creative if it is going to be successful at addressing serious policy issues in a way which is both intellectually rigorous and which considers the constraints posed by intensive household survey work.

In some respects, however, it is less a question of rigor and more one of who needs the information in the first place. Different groups of policymakers and analysts have different information needs. The choice of the method for collecting and analyzing data ultimately needs to be determined by the requirements of the user. These differences should help to clarify the tradeoffs between data quality and timeliness, short and long term data requirements, participatory research and the need for rigor.

A further challenge for researchers will be to evaluate the influence of spatial variables (such as the extent and access to forest, grazing, and water resources) on social and economic variables at the household level. Increasingly, household research must capture 
how agricultural production decisions are influenced by the household's physical location in the landscape. An even greater challenge will be to identify the impact of temporal changes in physical, social, and economic variables on the natural resource base (Scherr and Vosti 1993).

In any event, social and economic research at the household level about natural resource use must be clearly drawn into, and driven by, the policy process. For instance, possible research themes might focus on the impact of structural adjustment on woodland management. Conceivably, economic devaluations and liberalizations would increase the costs of chemical fertilizers to farmers, and this would result in greater pressures on woodlands for organic nutrients. In valuation studies, this would greatly increase the value of leaf litter collected from woodlands, and make a stronger case for their management and conservation. For most sectors, economic research at the household level has seldom been driven by such concerns, and more conventional themes have, for the most part, dominated.

In summary then, research about the role of woodland products in the household economy is a high priority. This research must increasingly focus on how households allocate different productive factors, particularly land, labor, and capital, in ways which affect woodland use and management. There is a real need for research at the household level, with substantive economic content, which considers the role and impact of differentiation on woodland use, risk and the diversification of inputs into the farming system, seasonality of access and use, food security, and the balance between subsistence demands for woodland products and their sale in the market. Valuation studies should be more carefully designed to explore decision-making at the household level vis-a-vis real or imputed values for woodland products. In characterizing the scope and nature of household studies, research should have clear policy links, and should be increasingly focused on questions of relevance to a broad range of policies. Finally, careful design of these types of studies is essential to address some of the methodological problems of past research.

\section{Woodland management for the market}

Many national forest policies in Southern Africa are geared toward limiting the commercial exploitation of woodlands. Control regimes, licensing, trafftc checkpoints, roadblocks, and increased royalty collection from users of woodland products from customary or communal lands have all featured prominently in the approaches undertaken by governments to limit woodland exploitation. The reasons for this are largely because there are a very limited number of policy, legal, or market tools which governments can (or are willing to) use to change how woodlands are exploited. Most of these policies focused on regulating woodland use, rather than on creating an enabling environment for woodland management.

Indeed, markets for products from woodlands are quite different from markets for agricultural and other commodities because of this. Agricultural commodity markets can be manipulated by a relatively large number of actions on the part of government: pricing policies, subsidies, credit regimes, input supply, labor legislation, and so on. Arguably, many of these policies are geared toward increasing the supply of agricultural commodities. Policies toward forest products, however, are typically geared toward limiting supplies of woodland products. Control regimes are among the more common of responses when forests and woodlands come under pressure, largely because there are few other instruments open to line ministries or departments with responsibilities for environmental protection. ${ }^{7}$

In many areas, for instance, the only legal rights which farmers have to exploit trees growing on land allocated to them is the right to cut them down in order to cultivate their land. There is no legal incentive to encourage regeneration or to maintain valuable timber trees until household income is needed or until prices are optimal, because revenues accrue to local authorities and not to households.

The approach of limiting woodland exploitation through controls and regulation is largely based on the assumption that the commercial harvesting of woodland products damages woodlands. While this is certainly true

${ }^{7}$ Nor are alternative instruments. commonly considered possible. Most Colonial natural resource legislation reflected a view that African areas had to be heavily regulated, while voluntary controls were encouraged in European farming areas. While the assumption is often made that these controls have been abandoned since independence, they continue to shape and influence patterns of land and resource use, and policies and legislation, throughout the region. 
for particular types of extractive processes (such as woodland clearance to meet demands for woodfuel for urban markets, for the tobacco industry, or for the railway and mining industries earlier this century), the harvesting of many extractive products poses little threat.

It is important, then, to characterize markets for woodland products as falling somewhere between two extremes:

- large-scale extractive industries which rely principally on the clearance of woodlands to meet market demands, with potentially serious negative impacts on productivity;

- extractive industries which rely on the harvesting of woodland products, with varying, but often lower, impacts on woodland productivity.

The question of the future of many woodland areas may rest in finding ways to link production for the market with active strategies to encourage their sustainable management. Tapping into markets, and into the process of specialization and exchange, in order to encourage rural households better to manage woodlands has proven to be a challenge for many rural forestry project planners, particularly in the face of counterproductive policy and legal instruments which argue against this approach.

\section{High impact extractive industries}

Markets for products which are harvested as a result of the large-scale extraction and/or clearance of woodlands pose very real problems. Of these, woodfuel markets present the greatest threat. They are probably the easiest to characterize, yet there are very few well-thought out studies of the operation of these markets, and of their impact on woodlands or on trees on farms. These types of large and potentially destructive markets require creative strategies for shifting production to less-intensive forms of management and extraction regimes or to onfarm production.

In understanding the policy dimensions of extractive industries, market interactions, and their impacts on woodlands, it is necessary to emphasize that many policies are derived from areas where governments believe they can achieve the greatest political advantage (rather than by the socially or economically-optimal).
For example, to strengthen the incentive for food production, governments can either allow prices to rise in the face of shortages, or can subsidize the costs of farm inputs (including the costs of capital and other factors of production). Though pricing policies may be more efficient in securing greater crop production, governments, particularly in Africa, prefer the latter approach because of its political advantages (Bates 198 1).

Rural subsidies are often coupled with urban price controls. For instance, rather than allow food prices for urban dwellers to rise, governments often choose instead to control prices, and to ration supplies. Rent seeking behavior on the part of food producers and intermediaries forces the market underground, and parallel markets emerge.

Similarly perverse effects can result from the application of these types of policies to the management of woodlands or to markets for tree products such as for woodfuels or construction poles. For instance, when urban markets for woodfuel are hit with 'shortages', energy planners often rely heavily on price controls to keep prices low and on the rationing of urban energy supplies. Price controls and rationing are often accompanied by heavy subsidies to encourage the use of alternative cooking fuels such as paraffin. Governments may seek to impose stringent penalties on those harvesting and transporting woodfuels to urban areas.

The outcome in these markets may be fuelswitching, and the emergence of parallel markets for woodfuel. Woodfuel harvesting, transportation and marketing may be driven underground, increasing potential returns to those willing to take the risk. As with policies which seek to keep the price of urban food supplies low (policies which, have little or no impact on encouraging farmers to grow more food) these types of energy policies do nothing to increase the incentive for farmers or communities to manage woodlands to produce woodfuels for the urban market.

Another point that should be emphasized is that rural people who engage in these markets are doing so to generate income. To rural households, woodlands and forests may appear to provide relatively abundant supplies of woodfuel which can be harvested and sold in nearby towns. Constraining the market may well jeopardize their livelihoods. The primary incentive of households which are engaged in harvesting 
woodfuel is for income generation, and not for their own woodfuel consumption (a point often lost on policy makers).

A transition to systems of sustainable production, then, may entail heavy investment costs in several respects: in terms of increasing income and employment possibilities for these households; in terms of introducing or strengthening incentives for local communities to protect valuable ecosystems; and in terms of intervening in the market in a way which encourages consumers who are dependent on woodfuel markets for their supplies to either consume less, to shift to the use of other fuels, or to start using woodfuel which is grown or managed on a sustainable basis (often at considerable cost). These types of approaches often go far beyond those allowed by the existing body of policy and legislation, as well as beyond what even the most innovative and well-financed of public sector institutions might be able to undertake.

\section{Small-scale forest or woodland based enterprises}

Markets for other types of woodland products have less pronounced impacts on tree cover, and less obvious impacts on woodland productivity. These markets are often still the subject of government control, regulation, and licensing, though there are growing doubts about the usefulness of this approach viz. the role of these enterprises in the rural economy. Small enterprises can provide rural households with many goods otherwise only available from commercial manufacturers at much higher prices. In terms of employment, they offer significant scope for rural households to supplement and diversify their sources of income, often with low investment and operating costs.

Small woodland or forest-based enterprises often operate where transportation is constrained, and where raw materials are dispersed. They are much more dependent on the collection or gathering of inputs, than are most other smallscale enterprises, and value-added is an important feature of these businesses. Pressures on woodland resources and the controls governments place over the extraction of products from woodlands in customary and communal lands have contributed to growing problems in the supply of inputs. Rates of paid employment are usually higher for the traditional forest industries: woodworking, sawmilling, and furniture making. Lower rates of paid employment are found in single operator types of businesses: traditional healers, beer brewing, fish processing, and retailing. Startup costs are low, and relatively easy entry and exit allows households to rely on these enterprises to diversify their sources of income, especially during times of greatest need ${ }^{8}$.

At the same time, easy entry into the market increases competition and makes it difficult for small enterprises to make the transition to larger, more viable businesses. Most woodland-based enterprises are too small to draw on rural credit facilities, and those that do find themselves in a policy environment which is geared toward larger industries (Arnold 1992).

There have been few programs which have been designed specifically to support small-scale forest or woodland-based industries. Support needs to be geared toward areas of competitive advantage, which probably lie in niche markets where enterprises can specialize in the labor intensive production of goods which cannot be otherwise manufactured (such as handicrafts). Even so, other evidence shows that the traditional forest-based enterprises (such as carpentry and woodworking) are much more able to compete and survive than single operator businesses based on other woodland products, which show only marginal returns to labor (Kilby and Liedholm 1986).

The literature about these types of enterprises, and their impact on woodland productivity, is extremely sparse. Perhaps the richest source of information is contained in a series of country studies of micro-, small-, and medium-scale enterprises (MSMEs) which were financed by USAID, and which were carried out in most SADC countries. In Malawi, for instance, of nearly 11,000 MSMEs which were enumerated in a national survey, around 17 percent were dependent, to varying degrees on raw materials from trees and woodlands. Further analysis and development of this existing data set could be extremely useful.

These types of studies need to be complemented by other more detailed exercises which assess the structure and function of very specific markets, for instance, for wild fruit or other woodland products such as mopane worms, thatch and cane, and herbal medicines. For

\footnotetext{
8 These were all findings from a recent review of small and medium-scale forest-based enterprises in Malawi; derived from data reported by Daniels and Ngwira (1992).
} 
policy and planning purposes, the analysis of these markets vis-a-vis the potential involvement of households and communities in woodland management would be extremely useful.

\section{Directions for market research}

We have emphasized that markets have different impacts on woodlands, depending largely on the intensity of extraction. High impact, extractive, industries pose real challenges for policy and planning if a balance is to be maintained between the need for the type of product which is serviced by these markets, the desire to conserve woodland areas, and the need for rural income and employment. Control regimes, licensing arrangements, and so on have largely been geared toward constraining these markets and reducing their impact on woodland cover.

Nonetheless, these markets won't go away. They are often a critical source of income and employment in rural areas and provide badly needed goods, such as woodfuel, to urban centers. Governments have consistently found that the high social costs to both of these sectors, which come about as a result of constraining the market, create political and economic difficulties.

We have suggested that a transition to systems of sustainable production for these markets will likely entail heavy investment costs in several respects: in terms of increasing income and employment possibilities for rural households; in terms of introducing or strengthening incentives for local communities to protect and manage valuable ecosystems; and in terms of intervening in the market in a way which encourages consumers who are dependent on these markets to either consume less, to use substitutes, or to use supplies which can be sustainably managed.

All of these areas pose considerable challenges for the research agenda. Market research needs to be broadly based, and should consider,

- the extent of income and employment associated with particular markets; possible employment alternatives; social costs of limiting the operation of these markets;

- links in the market chain, between sources of supply and centers of demand; how can policy and legislative initiatives be targeted at specific links in the market chain to encourage the adoption of sustainable management systems; focus on removing constraints to markets for alternative sources of supply; impacts of markets on woodland cover: how can supplies be shifted to areas which can support greater rates of extraction.

what are the potential and comparative advantages of substitutes;

what constrains communities and/or households from managing woodlands to provide supplies for the market on a sustainable basis; how can these constraints be removed.

These areas of research are also of some relevance to small, woodland-based enterprises which depend on widely dispersed sources of input supply. These markets, however, pose a number of other challenges. Research into the operation of small-scale woodland-based enterprises should consider, developing and expanding upon existing studies of micro-, smalland medium-scale enterprises (MSMEs), with a view to more accurately characterizing the operation of woodland-based enterprises vis-a-vis MSMEs as a whole; and focusing on a number of specific markets for non-timber based products (wild foods, fibre products, etc.), and how they operate.

These initiatives should carefully consider household impacts of market operation with a view to exploring the potential of households and communities as woodland managers. As with other elements of this research agenda, linking these initiatives with the policy process is of considerable importance so that an understanding can be developed of how markets can be influenced by policies and legislation.

A central and underlying theme which should help to guide market research has to do with who has the rights to benefits from woodland management as discussed above.

\section{Longer term social, economic and environmental change}

There is relatively little research which has been carried out on longer term patterns of social, economic, and environmental change in southern Africa. That which has been carried out provides compelling evidence that contemporary patterns 
of land-use and woodland cover are the outcome of much longer term processes. While the short term impacts of rapid population growth seem quite clear -- that natural systems are often placed under extremely heavy stress as a result of population increase -- longer term impacts are more encouraging.

For example, a remote sensing study carried out in Zimbabwe in 1984 drew several conclusions about deforestation, suggesting that present patterns of land clearance had been established many years earlier, and were strongly associated with the pattern of agricultural landuse, rather than with extractive processes per se (such as demands for woodfuel):

Areas which were the most deforested at the time of the study were generally those which were the most deforested around 20 years earlier.

- Deforestation in the study area was strongly related to the clearance of arable land for cultivation.

Although deforestation had been well advanced 20 years earlier, there had been considerable additional clearance of land for cultivation.

- In deforested areas where remaining wood resources are essentially confined to noncultivable locations (particularly hilltops), the significant clearance of residual woodlands had not taken place over the previous 15 to 20 years. In fact, some areas of residual woodland appeared to be more densely forested at the time of the study than before, perhaps because of coppice regrowth (du Toit et al. 1984).

Longer term studies, which have relied on historical and archival records rather than on remote sensing data, suggest that even amongst the most intact of woodlands, there is very little unmodified miombo anywhere. In Malawi, for instance, heavily modified miombo accounts for over 95 percent of existing woodland cover (Hardcastle 1993). Mature miombo in the Tabora region of Tanzania is mostly regenerated, having been agricultural land in the 1860s which was subsequently abandoned because of an outbreak of sleeping sickness in the early 1900s (Lawton 1982).

These types of transitions in land-use are extremely enlightening for the policy process because they suggest that miombo woodlands are very resilient to many of the pressures placed on them. Much of the policy dialogue about the environment at the regional and national level in southern Africa (as well as internationally) is very negatively oriented: population growth will place increasing and inexorable pressures on natural environments and there are few approaches which can be taken to mitigate the impacts of these pressures. Policy and legislation, rather than mitigating these impacts, has in some instances, amplified them. Longer term studies, can help to identify both the positive steps which have been taken in response to these pressures as well as the policy initiatives which should be avoided in the future.

There are very few studies which have taken this approach. In Zimbabwe, McGregor (1991) pointed out that technical exercises to rationalize land-use, dating from the late 1920s, had serious and profound impacts on woodland cover. Planners encouraged the clearance of woodlands in upland areas for arable cultivation, and shifted grazing blocks to lower, unwooded areas. This imposed a reversal in earlier land uses, and greatly limited access to productive woodlands.

In Malawi, woodlands have been managed by communities both under customary arrangements, and under arrangements which conferrod legal rights of use as Village Forest Areas (VFAs). Legislation which gave recognition to VFAs first came into force in 1926. VFAs were an institutional construct which sought to give clear rights of tenure over local wooded areas to communities; Their origins in customary tenure were probably derived from the rights of chiefs to create small protected areas for hunting purposes. The protection of wooded areas as sacred sites or for production purposes for use by communities is a feature of customary tenure throughout southern Africa. While it is likely that community use and control of, wooded areas extended beyond the constructs of VFAs, there is little information documenting these processes. By 1934, around 2,900 VFAs had been establishing, covering over 64,000 ha. Management consisted mostly of early burning, protection against illegal cutting, protection from grazing, and the cutting of tall grass prior to controlled burning (Hardcastle 1993).

Although there are over 2,000 recorded VFAs still 'on-the-books', most of them remain in name only. The system fell into disuse in the 1950s and early 1960s, as other priorities overtook the Forest Department and local administrations. In some areas, however, VFAs have been revived and remain an important 
tenurial concept. They pose some potential for the involvement of communities in the protection and management of woodland areas.

In areas where communities have taken an interest, VFAs continue to be demarcated. There are several studies of the local management of woodland areas in Malawi (Coote et al. 1993a, 1993b). Legislation is currently pending which seeks to revive VFAs as management institutions.

ln Zambia, long before Independence, land ownership was vested in the hands of a traditional Barotse leader, the Litunga. In 1936, the Barotse Forest Orders were drawn up which laid the basis for woodland use and management into the 1970s. Under these Orders, the Litunga and his administration was entitled to revenues from forest management (mostly from the extraction of Zambezi Teak) and could reserve woodland areas for management. Outside of reserved areas, the Litunga encouraged bush clearance for crop production, but made special orders for the preservation of fruit trees. The Barotse National Government Forest Service was created to undertake woodland management, and skilled foresters as well as lineage authorities were responsible for the implementation of the Forest Orders. This reliance of lineage authorities to undertake woodland management was highly successful, and revenues from the forests provided a significant proportion of total government revenues.

The Forests Act of 1973 withdrew all rights of the Litunga to own land. Though the Barotse Forest Orders provided the basis for the Forest Laws of Zambia, the lack of an effective and locally respected means of administering local management planning has meant that management standards have badly deteriorated. The impact has been severe:

.... The withdrawal of the Litunga's rights to claim royalties from the forests and to preside over land matters drastically changed the peoples attitudes towards the forests. They no longer felt that the forests were for their own benefit. Chances for employment in the forestry sector became remote. They could no longer easily acquire farmland they had to pass through a lot of Government bureaucracy... (The repeal of the Barotse Forest Orders) drastically transformed the people's attitudes towards the forests and forest conservation began to suffer (Matakala 1986).

Two other studies from outside the region are worth noting as examples of extensive multi- sectoral investigations of long term processes of land-use change. Tiffen et al. (1994) undertook a study in Machakos District of Kenya covering the period from 1930 to 1990 which sought to explore the relationship between population density, productivity, and environmental degradation. They concluded that 'population increase is compatible with recovery from environmental degradation, provided that market developments make farming profitable.' Studies of vegetational change over the period showed, among other things, a great increase in the woody component of grazing lands. In Northern Machakos particularly, increasing woodiness was found to be an outcome of intentional conservation strategies, rather than a result of livestock grazing.

Fair-head and Leach (1993a, 1993b) report the results of longer term studies of forest use and conservation in Guinea. Relying on detailed descriptions of their study area dating from the mid-1800s, they concluded that conservationists entirely lacked an understanding of the dimensions of local land- and forest-use. Referring to the Ziama Forest Reserve, they noted that

... (R)ecent approaches have attempted to secure local support by linking conservation to socioeconomic benefits for local communities, whether from (the reserve). . . or from 'compensatory' rural development activities around it. These economic possibilities provide grounds for establishing 'participatory' conservation planning (Fairhead and Leach 1993a, p. 1.)

Commenting on the considerable evidence of long settlement in an area which was subsequently reserved, they pointed out that this short term view was entirely inadequate because it considered forest degradation a result of recent immigration and other demographic and economic pressures. A series of wars in the late 1800 s resulted in local migration out of farming areas, and into adjacent lands. Much of what has been reserved consists of extensive secondary forests on old settlements, and families relocated from abandoned villages still retain their longstanding claims over their ancestral lands.

Local antagonism towards the reserve which has built since its establishment cannot be understood outside this historical context.... 'Participatory' forest management will not prove possible until such historical claims to land and political authority are on the agenda. It is entirely 
inadequate to consider only modern economic needs and pressures, important as these might be (Fairhead and Leach 1993a, pp24-25).

We have focused here on four types of studies of long term change in woodland use and management.

remote sensing studies, which have shown patterns of land-use and woodland change (Zimbabwe)

- $\quad$ studies of the historical and legal basis for the local management of woodlands to highlight the current potential for reintroducing earlier, viable local management strategies (Malawi and Zambia) multisectoral long term studies examining environmental change within cultivated areas in the face of changing social and economic conditions (Kenya)

longer term studies of land-use change in reserved forest areas, giving perspectives on local conflicts over conservation (Guinea)

\section{Policy, legislation and macroeconomic impacts on woodlands}

\section{Impacts of forestry and natural resource policies and legislation}

Much of the research agenda discussed so far has focused on micro-level issues. A larger question is of their relevance at the policy level, to the economy as a whole, and to the development of legislation. Social and economic research should, in many respects, be driven by the policy process, though they are often undertaken independently. This is partly because responsibilities for and interests in different types of research rest with different institutions, and partly because there are few institutions with the capacity for undertaking research initiatives covering such a broad area. Because policy formulation is the responsibility of national-level institutions, policy research per se is usually undertaken either by, or in close cooperation and collaboration with, these institutions. A concern is that, because of these types of ties, policy research tends to be co-opted by political processes within these institutions, and this undermines its credibility.

Within the region, few national institutions have a well-developed capacity to undertake policy, legislative, or macroeconomic research. National institutions with natural resource management responsibilities are usually staffed with foresters, wildlife specialists, ecologists, and other scientists. Staffing policies and manpower constraints have limited the possibilities of employing staff with the training to carry out policy research. Recognizing the need for better information, senior management in some institutions has encouraged junior staff to explore areas of special interest to them of relevance to the policy process. While not the optimal situation in terms of involving trained manpower in policy initiatives, this approach has produced some promising results. To inform more fully the policy process, there is a very considerable need for sustained local support for policy research.

A considerable amount of policy research in the region with regard to miombo woodlands has been supported, undertaken, and in some cases, instigated by international development assistance agencies. While the process hasn't been as one-sided as it sounds, aid agencies have their own agenda which may not coincide with national priorities and interests.

Indeed, policy formulation may be the victim of its numerous constituents, which may include aid agencies, rural people, traditional authorities, civil servants, and academics. All of these groups have different competing, or sometimes complementary, interests. The policy outcome is not always in favor of how society best will be served, but who has the most political clout. The use of policy research to promote a political agenda is an unfortunate, but inevitable, outcome.

Much of this discussion has focused on how appropriate policies can ensure long-term access for rural communities and households to benefits from woodlands in southern Africa. Especially in this respect, policy research must consider the scope and nature of natural resource-related policy and legislation and how it has affected woodland cover. Although contemporary woodland management and use are in part a longer term outcome of policies and legislation which date from earlier periods, an assessment of the more recent experience is critically important as well. Policies have seldom been developed independently of past experience. Rather, they build on these earlier policies, and use new information as it becomes available and as new development priorities emerge. Research must explicitly recognize and take into account the dynamic nature of policy formation (see particularly the discussion in Gregersen et al. 1992). For instance, a concern about the woodfuel crisis' focused policies and project planning on developing effective responses to 
what were perceived to be growing woodfuel shortages. There is increasing agreement that wood energy policies are in serious need of reassessment, as they were based on a number of weak premises about the nature and impact of energy supply and demand.

Much natural resource legislation in southern Africa reflects the dualistic nature of earlier policies which were fundamentally regulatory in nature. In customary lands, an emphasis often remains on regulated control of natural resources with few options for the encouragement of active participation in resource management by local populations. Obvious conflicts developed where there were strong local traditions of resource management which were at odds with the models of management imposed by the technocracy. There is a growing need to introduce policies which enable local people to manage, rather than to regulate management.

The conflict between the desire to involve local people in more intensive natural resource management and the statutory requirement to enforce existing regulations is clearest in national forestry institutions which have both extension and regulatory responsibilities. In many instances, these responsibilities need more clearly to be separated.

A final point to make about the nature of policy research is that it has usually been reactive, rather than pro-active -- undertaken in response to the concerns of one (or of a group of) constituent, rather than as part of an on-going process. There are encouraging signs that this is changing in southern Africa, that public sector institutions are increasingly aware of the longer term impacts of policy change, and that policy research is being used to develop an understanding of some of these impacts.

\section{Intersectoral policy linkages}

Agricultural and other land-use policies. The most profound impacts on woodland cover in southern Africa were not the result of forestry policies, but of other attempts to regulate and control agricultural and other land-uses. For instance, various programs between the 1950s and 1980s relied on the implementation of a technical exercise to 'rationalize' land-use, by consolidating villages along roadsides, and demarcating arable and grazing blocks based on calculations of carrying capacity. These initiatives were often linked to cattle destocking programs.

In some areas, this period had a major impact on woodlands. Planners sought to shift arable production away from water resources (such as dambos and streambeds) to wooded toplands. Grazing areas were shifted from these areas to lower, often unwooded, slopes. The outcome of these shifts was woodland clearance on a massive scale in support of arable production.

More recent resettlement schemes have also had a significant impact on woodlands. Settlement of wooded areas has been increasingly possible because of tsetse eradication programs. Some of the most rapid rates of woodland clearance are being encountered in former tsetse areas.

Rapid woodland clearance has posed considerable problems for the agricultural sector. In areas which have been long-settled, institutions have had a longer time to adapt to environmental stresses and to the stresses imposed by increased population pressures. The functional role of these adaptive processes has been to broaden the range of responses open to households, including a reliance on wild food resources and other woodland-derived benefits. This type of diversification has not been immediately available to resettled households which have moved into new environments with different soils, vegetative types, and climatic conditions. Arguably, productivity will fall and malnutrition rates in areas of resettlement will remain high until households are able to develop adaptive responses to environmental stress, and the institutions within which these responses can be framed.

An underlying issue for planners and policy makers has to do with the need to maintain land under woodland cover in the first place. There is considerable evidence that, within viable institutional constructs, agricultural intensification in woodland areas, resulting in heavy woodland modification and clearance, increases both agricultural production and the diversification of inputs into the farming system. When these processes accelerate to such an extent that few productive woodland elements remain, there are considerable costs to the economy in terms of the need for alternative inputs. The balance between woodland modification, demands for new agricultural land, and the longer term costs of the loss of woodland cover must all be assessed during the policy process. There are unfortunately few tools which can enable planners to fairly assess these costs and benefit, and how they should be weighted in the policy process. The further expansion of agriculture in already settled areas, and pressures 
on woodlands associated with this expansion, can largely be accounted for by the growth of the resident population. Depending on the nature of local resource management institutions, responses to these stresses can be moderated by adaptive processes. The pressures on woodlands which are the most difficult to moderate are those which are brought about by the in-migration and by the rapid settlement of new populations in wooded areas. Migration, and the factors which cause it, is of considerable concern because of its impacts on both dry and wet tropical forests and woodlands.

Structural adjustment and the environment. Structural adjustment, whether externally imposed in exchange for increased lending by development assistance agencies, or internally adopted as an element of national planning, has become an increasingly important means of economic management. Structural adjustment may involve the floating of exchange rates, liberalized trade and interest rate policies, a rationalization of taxation policies, banking and public sector reform.

Most analysts accept that sustainable development is intractably linked with environmental stability. Arguably, structural adjustment should be seen as a process which contributes to sustainable development and, hence, to environmental stability. Nonetheless, structural adjustment programs seldom focus on anything more than their immediate impacts on national economies. This is understandable. Structural adjustment involves discrete mechanisms for economic management which produce measurable changes in economic performance over the short and medium term.

While understandable, it is not desirable. It is increasingly accepted that structural adjustment programs can have social impacts or can contribute to broader objectives such as poverty alleviation, distributional objectives, and a reorientation of public sector financing toward education and health. There have been few efforts, however, to understand the impact of structural adjustment on a country's natural resources (some of the few attempts to do so are reported in Reed, 1992) .

Structural adjustment may be linked to sectoral lending programs, through which aid agencies agree to lend funds for structural adjustment provided that certain sectors are liberalized. For instance, lending may be committed on the condition that fertilizer subsidies are removed or that crop prices are decontrolled. Sectoral lending which is contingent on reform in the natural resources sector is virtually unheard of.

Some aspects of adjustment have unintended consequences on the environment. For instance, exchange rate adjustments which resulted in a devaluation of a country's currency would make it more lucrative to export valuable hardwoods and timber products. This is all good and well -- an intended outcome of adjustment. Most timber, however, is not sold at rates on-thestump which reflect its export value. A devaluation would greatly reduce the cost of roundwood on-the-stump as a proportion of the export price, considerably increasing the incentive for extraction, and speeding up the rate at which valuable hardwoods are depleted from miombo and other woodlands.

A more sensible approach would have linked adjustment policies with sectoral reform which coupled devaluation with concession policy reform. This would ensure government was capturing rents for valuable hardwoods, for instance, by selling concessions at auction or by more quickly responding to a devaluation with adjustments to the schedule of royalties.

Even in the best of circumstances, sawmillers are going to complain about increases in royalty rates. Millers in Zimbabwe, for instance, complain that domestic timber is more expensive than imported European hardwoods. Arguably, this is as it should be. The result of increased royalties though will be unemployment in the timber industry, or the reallocation of resources to more productive sectors.

Liberalizations often result in incompatibility between different policies. Wood energy policy in Malawi, for instance, is geared toward increasing investments in plantations and woodlots in identified wood deficit areas, and to reduce rates of woodland exploitation by controlling woodfuel flows into urban areas. Government also maintains the price of plantation-produced firewood at low levels to mitigate the impacts of price increases on urban consumers. There is an essential contradiction between these policy objectives if Government intends, on the one hand, to encourage investment in plantations and woodlots, while, on the other, seeking to keep the price of plantation production low. Policies are incompatible which attempt to limit woodland extraction, but which keep the price of woodfuel from rising in response to economic scarcity.

Similarly, liberalized energy policies which favor the adoption of marginal-cost energy 
pricing result in higher prices for conventional fuels such as paraffin, coal, or electricity. Fuel switching to cheaper substitutes will result, likely causing a heavier dependence on woodfuels in the short term and faster rates of woodland clearance.

Structural adjustment programs often argue in favor of blanket decontrol and market liberalizations. While this might improve, for instance, food security, some markets have traditionally been controlled because of concerns about the impacts of decontrol on the environment. Arguments for market control are strongest where markets have failed. Open access resources are especially subject to market failure. In these instances, blanket liberalizations could have seriously negative impacts on woodland cover, unless clear initiatives are undertaken which seek to mitigate these impacts.

Subsidies are a common target of structural adjustment programs. They are an often expensive means of shifting economic activity toward particular sectors. Fertilizers are often subsidized. Devaluation coupled with a removal of fertilizer subsidies can greatly increase the cost of these inputs to rural households. The removal of subsidies could significantly improve the economic viability of agroforestry systems, or could increase the value of managing woodlands for the production of leaf litter. ${ }^{10}$ If it is accepted that subsidies need to be removed, this policy should be coupled with active steps to shift nutrient management to more sustainable household-based systems.

Higher crop prices, which can be an outcome of structural adjustments, arguably increase the rate of agricultural land clearance. Most available evidence shows that this is going to happen anyway. The question is more one of how it can be brought about in the least-cost way to the environment. Studies by Tiffen et al ( 1994) strongly indicate that environmental improvements can be anticipated, even in the most degraded of dryland areas, if market developments and technical change are coupled with focused public investment. Careful design of these types of initiatives which considers their

\footnotetext{
${ }^{9}$ In the medium and long term, woodfuel prices will likely increase in response to increased prices for commercial fuels.

${ }^{10}$ Leaf litter is commonly used as a fertility input in Zimbabwe. Its use elsewhere in southern Africa is poorly documented.
}

impact on woodlands is urgently needed. . Research to date has failed to inform on this important subject.

There is no easy answer to the problem of structural adjustment. The means for exploring the impact of adjustment programs on woodlands have not been widely reviewed or discussed. Macro incompatibility makes the implementation of research findings problematic because of competing objectives of adjustment. Complementarity between policies which seek on the one hand to improve economic performance, while on the other are geared toward natural resource conservation and management, is uncommon.

\section{Are miombo woodlands valuable? For whom and for what?}

Valuation ... again. . Valuation was discussed to some extent above. We pointed out that valuation studies have different audiences and can be used for different purposes. For instance, valuation of publicly-owned woodlands may be of interest for helping a national forestry department to identify how these lands should be used in the future. Valuation of privately-owned woodlands may be of use in establishing rates of taxation, or rates at which governments should be compelled to buy land which has been acquired by compulsory purchase. Valuation could also be used to make the case that some lands are underutilized and could be far more economically productive under alternative management regimes. Finally, valuation studies can be used as an input into a system of 'green' national accounts.

The way in which valuation is considered and carried out must, in large measure, reflect the concerns of the end user. More than with other types of micro-level research, there are clear dangers for multiple user groups to extrapolate their own conclusions from the results of valuation studies.

At the household level, the obvious questions to ask are, firstly, what benefits from trees do farmers most value, and secondly, have these benefits provided (or could they provide) any incentives for households or communities to conserve and manage miombo woodlands. The first of these questions can be addressed by exercises such as contingent valuation or farmgate pricing. In Zimbabwe, for instance, households which were involved in a contingent valuation exercise placed the highest value on benefits from fuelwood, building material, and 
from tree-derived inputs for crop productio (Campbell et al . 1991).

This still tells us little. Valuation exercises usually only assess the total value of specific benefits to the household, and do not consider either their relationship to source or quantity. Conventional valuation exercises also fail adequately to reflect the real value of some products to households (Behnke 1985). Farmgate price estimates and willingness-to-pay exercises tend to overvalue some commodities and undervalue others, particularly when they are used as a guide for establishing how farmers manage trees and other woody cover. Taken at face value, for instance, results from the Zimbabwe contingent valuation exercise suggest that high values placed on woodfuel and building timber should provide important incentives for farmers to plant trees or to otherwise manage woody cover. Studies of tree planting practices in Zimbabwe, however, have indicated that farmers have principally planted trees for fruit and for shade (Campbel et al. 1991). Valuation exercises tend to obscure the relationship between the costs of using particular commodities, and the benefits associated with their use. For example w,oodfuel may be derived from a wide range of sources: miombo or mopane woodlands, trees growing on farms, trees in fields, recycled timber or construction material, and so on. The number of pecies which can provide woody biomass for woodfuel is quite high. There are also a range of potential low cost substitutes for woodfuel may be derived amount of woodfuel used, and its value, may be quite high, the value of woodfuel derived from any single source may be quite small. Particularly when woodful is collected opportunistically, the costs of extraction are low and perceived benefits of its use high. The incentive to replace particular extractive strategies with woodfuel from planted trees or from more intensively managed woodlands (which require investments of both capital and labor) will remain low.

The few valuation studies which have been carried out of woodland products in Southern Africa seem to be empirically sound. They are, however, heavily qualified and based on a series of well-articulated assumptions. The problem for policy making, is that these qualifications and assumptions are often lost or obscured when the results of these studies are translated by others into a form which can be more easily understood for a larger, perhaps non-academic, audience to make a particular point.

We offer as an example results reported in Campbel et al. (1991) which assessed market values and replacement values for a range of woodland and tree products used by households. These are given in Table 1 . The results are reported in terms of market values and replacement values of benefits from woodlands and trees, per household, and is heavily qualified by the assumptions given in the notes to the table. These notes make it clear that the study was only valid for sampled households in specific agroclimatic zones and that the results were based on a clear set of quite limited assumptions. The results applied to all benefits from trees and were non-specific about the type of trees or woodlands from where the benefits were derived. There were careful textual qualifications which emphasized that the study did not consider marginal utility, and that most farmers in the study area operated outside of the market and lacked the income to purchase these goods at market prices. A table from a second report, which drew on the Campbell study, is given in Table 2. This table, and the text which accompanied it reported the results of the Campbell et al. study in terms of 'private woodland benefits' per ha of woodlands - even though the original study never suggested it referred only to woodland benefits or that there was sufficient information to conclude for each product that household benefits were derived from a specific area of woodland.

There were few textual qualifications in this report, and the impression was conveyed that the results hold true for all woodlands in Zimbabwe across all agroclimatic zones and were independent of the households and the social and economic characteristics from which the information was originally derived and on which the results are heavily dependent.

For the policy analyst who uncritically examines the second table, the next steps are clear. Find an estimate of the area of woodlands in Zimbabwe, and multiply this by the annual woodland value per ha given in Table 2. The results would be fatuous and have no empirical basis. The point here is only a cautionary one. Contingent valuation, hedonic pricing, and the assessment of market or replacement values all have their strengths and weaknesses. While there is great utility in the further development and application of these methodologies for clarifying woodland values, we emphasize that they have 
Table 1. Market values and replacement values for benefits from woodlands and trees, per household.

\begin{tabular}{l|c}
\hline Woodland benefit & $\begin{array}{c}\text { Annual value of woodland benefits } \\
\text { (1991 Z\$ per household) }\end{array}$ \\
\hline Wild fruit (a) & 230 to 360 \\
Other wild food s ${ }^{(b)}$ & 63 \\
Fuelwood (c) & 183 \\
Construction wood (d) & 114 \\
Leaf litter & 134 \\
Livestock browse and fodder (f) & 100 to 160 \\
Wooden utensils and implements $(\mathrm{g})$ & 16 \\
Materials for craftwork (h) & 7 to 18 \\
\hline
\end{tabular}

Source: Campbel et al. (1991)

Notes: Values reflect benefits derived from specific woodland types and agroclimatic zones. Mangwende is in higher potential Natural Region (NR) IIa. Mazvihwa is in semi-arid NR IV. The Mutanda Resettlement Area, in the Save Catchment, is in NR III/IV. Binga is in NR IV. Prices are reported market prices (or replacement values), and do not reflect the value of benefits at their point of woodland origin.

a) Based on values for Strychnos cocculoides. Assumes that all production (34 fruit per tree) from 38 trees per ha (typical of Save woodlands) are sold in markets for 5 cents per fruit. Households use fruit from 3.5 to 5.6 ha of woodlands. b) Based on frequency and value of consumption of mushrooms, insects, wild vegetables, and honey reported in Mangwende. c) Based on 6.5 tons per households, reported for Mutanda, and rural cost for fuelwood of $Z \$ 28$ per ton. d) Based on 2 tons per household, reported for Mutanda, and rural cost for construction timber of $2 \$ 57$ per ton. e) Based on Compound $\mathrm{D}$ replacement costs for 3 tons of leaf litter per household at $1.35 \% \mathrm{~N}$ by dry-weight 40 percent of households use leaf litter. Compound D valued at $\mathrm{Z} \$ 0.60$ per kg. f) Derived from data for Mazvihwa, and assuming that the amount of livestock which grasslands can support is 25 percent lower than an area with scattered trees. g) Based on data for Mangwende, for implements and utensils made of local wood, owned per household, and data about durability and price. h) Assuming 14 percent of households sell crafts, and that average earnings per household range from $\mathrm{Z} \$ 53$ in Mangwende to $\mathrm{Z} \$ 130$ in Binga.

Table 2 . Valuation of private woodland benefits, per ha of woodlands.

\begin{tabular}{l|l|c|c}
\hline Rank $^{(\mathbf{a})}$ & Product & $\begin{array}{c}\text { Annual value of woodland benefits } \\
\text { (1991 Z\$ per ha of woodlands) }\end{array}$ & $\begin{array}{c}\text { Share } \\
\text { (Percent) }\end{array}$ \\
\hline $\mathbf{1}$ & Fruit & 65 & 34 \\
$\mathbf{2}$ & Fuelwood & $42(32-51)$ & 22 \\
$\mathbf{3}$ & Improved crop production through & $32(24-39)$ & 17 \\
& leaf litter & $27(20-33)$ & 14 \\
4 & Construction wood & $15(11-18)$ & 8 \\
5 & Wild foods & 5 & 3 \\
-6 & Improved livestock production & $4(3-5)$ & 2 \\
7 & through better grazing & $3(1-5)$ & 2 \\
8 & Wooden implements & $191(161-221)$ & 100 \\
\hline
\end{tabular}

Notes: (a) The rank refers to the mid-interval value, as does the relative share column.

Source: Bojö (1992). 
great potential for being distorted, intentionally or not, for the purposes of addressing an agenda for which they were not originally intended.

Revising systems of national accounts. There have been a number of efforts to revise systems of national accounts to consider the value of the environment, and the impact of its degradation or improvement on GNP. While the depreciation of man made capital is accounted for in most systems of national accounts, the depreciation of capital in the form of natural resources is nowhere usually considered. For the economies of Southern Africa, the overexploitation of dry woodlands by the railway, mining, and timber industries, has nowhere been reflected in national accounts, nor are the considerable benefits, both real and potential, from miombo management considered. There have been a number of studies which have sought to develop alternative systems of national accounts, with applications to Costa Rica (Solorzano et al. 1991), Mexico (van Tongeren et al 1991) and Indonesia (Repetto et al 1989). Experiences with these types of studies have increasingly shown that the practical difficulties of putting together a system of national accounts which reflects environmental values are considerable. Because of this, we will not elaborate further, to say that it is a subject under consideration amongst many research institutions, and might benefit from discussion in Southern Africa.

\section{Woodland conservation and management Optimizing land use in the drylands of Southern Africa}

There are very considerable questions about whether miombo and other types of woodlands in Southern Africa should be retained in the face of very heavy pressures for agricultural land throughout the region. Under the most intensive uses, especially in drier zones, woodland management holds potential for generating good returns compared with other land uses. Pressures for land, and the need to optimize the use of a diminishing resource, are precisely why woodlands in drier areas are so productive. This is arguably less the case in higher potential zones.

The use of woodland areas for wildlife management in a way which returns substantial levels of income to people living in customary lands has been attempted with some success in several regions of Southern Africa. Institutional mechanisms for devolving control over migrant natural resources such as wildlife to local communities are the subject of ongoing research. This type of land use is only possible where alternative woodland uses do not compete with wildlife. There are considerable questions about whether this is widely the case in the more heavily settled parts of the region.

Research must more carefully consider the options to rural families and communities in the absence of woodland cover, however sparse. It has been argued that woodlands need to be conserved and managed partly because of the large number of low-cost inputs which they provide to farming systems (Bradley and McNamara 1993). In the absence of these inputs, capital intensive alternatives (chemical fertilizers, cooking paraffin, alternative construction materials, and so on) would have to be provided in order to maintain agricultural productivity and rural livelihoods. There is clearly scope for macroeconomic research which considers these issues.

\section{Scope for research}

This section has argued that sustained support for policy, legislative, and macroeconomic research could usefully build on the existing body of research in these areas and would contribute to improving the environment for woodland management in southern Africa.

Research which would complement the existing body of work could be undertaken in a number of key and related areas, particularly:

- the impacts of natural resource policies and legislation on woodland use and management at the household and community level, focusing on the potential for developing a policy framework which enables woodland management rather than regulates it;

- the impacts of other sectoral policies (land use, agricultural, range management policies and so on) on woodland cover;

the impact of macroeconomic policies, such as structural adjustments and trade liberalizations, on natural systems, including woodlands;

carefully focused studies of the value of woodlands, with emphasis given to the appropriateness of different methods for particular user groups. A related research theme has to do with revised systems of national accounts which reflect the values of woodland use and management; and 
the costs and benefits of different land use options vis-a-vis woodland use and management, considering the investment which would be required to replace benefits lost as a result of woodland clearance.

\section{Woodland research options and opportunities: a summary}

This paper has focused on five areas of social and economic research relating to miombo woodland management in southern Africa:

1. Patterns of local institutional change. Land and tree tenure. Rights of use and access to woodlands. Gender issues. Resource sharing on state lands. Capability of community-based institutions to plan and implement local management. Appropriateness of 'participatory' approaches. Scope for linking woodland management with investments in resource conservation.

2. Household use of woodland products. Role of woodland and tree products in household production strategies. Risk and decision making processes. Differentiation and woodland use Valuation.

3. Markets for woodland products. Function and operation of both large, high impact extractive industries and small, less intensive woodland-based industries. Employment characteristics. Sources of supply. Impacts of policy and legislation. Scope for investment.

4. Longer term dimensions to woodland use and exploitation. Earlier natural resource and land-use legislation and policies and their impact. Physical extent of woodland cover over time. More recent impacts of policies on existing practices at regional and local levels. Economic and social change and its relationship to environmental change. Political processes and rural communities.

5. Policy and legislation. Impacts of contemporary natural resource policies and legislation on woodland use and management. Consideration of broader policies, rather than forestry policies alone: land-use policies, structural adjustment, crop input pricing policies, access to credit, agricultural policies, etc. Intersectoral linkages. Scope for bringing about environmental improvements through market development and technical change. Use of valuation studies. Revised systems of national accounts which consider environmental values.

In summary, then, there are a number of common themes which have influenced and shaped local-level miombo woodland management and use throughout Southern Africa. These themes are by no means definitive or exhaustive, but are described here as a means of focusing on the scope of future research.

\section{References}

Arnold, J.E.M., and Stewart, W.C. (1991). Common property resource management in India. Tropical Forestry Paper No.24. Oxford, Oxford Forestry Institute.

Arnold, J.E.M. (1992). Policy issues related to the role of trees in rural income and welfare security. In Priorities for forestry and agroforestry policy research: report of an international workshop (ed. H. Gregersen, P. Oram, and J. Spears), 15-3 1. Washington, DC., International Food Policy Research Institute.

Bates, R.H. (198 1). Markets and states in tropical Africa. University of California Press, Berkeley.

Behnke, R.H. (1985). Measuring the benefits of subsistence versus commercial livestock production in Africa. Agricultural Systems. 16, 109-35.

Bojö, J. (1992). Economic valuation of indigenous woodlands in Zimbabwe. Working paper prepared for the Zimbabwe National Policy Review of Forests and Trees. Washington, D.C. World Bank. 
Bradley, P.N. (1990). The role of trees and woodland in Zimbabwe's communal areas. Stockholm, Stockholm Environment Institute.

Bradley, P.N. and McNamara, K. (1993). Living with trees. Policies for forestry management in Zimbabwe. Technical Paper No.2 10. Washington, D.C., World Bank.

Campbell, B.M. (1987). The use of wild fruits in Zimbabwe. Economic Botany. 41, (3), 375-85,

Campbell, B.M., Vermeulen, S.J. and Lynam, T. (1991). Value of trees in the small-scale farming sector of Zimbabwe. Ottawa, International Development Research Center.

Coote, H.C., Luhanga, J.M., and Lowore, J.D. (1993a). Community use and management of indigenous forests of Mala i: the case of Chemba Village Forest Area, Unpublished report. Zomba, Forest Research Institute of Malawi. April.

Coote, H.C., Luhanga, J.M., Dembo, M., Banda, E., Lowore, J.D., and Abbott, P. (1993b) Community use and management of indigenous forests in Malawi: the case of three villages in the Blantyre City Fuelwood Project Area. Unpublished draft. Zomba, Forest Research Institute of Malawi. May.

Daniels, L., and Ngwira., A. (1993). Results of a nationwide survey on micro, small, and medium enterprises in Malawi. Technical Report No.53. Bethesda, GEMINI. January.

du Toit, R.F., Campbell, B.M., Haney, R.A. and Dore, D. (1984). Wood usage and tree planting in Zimbabwe's communal lands. Harare, Forestry Commission of Zimbabwe and the World Bank.

Fairhead, J. and Leach, M. (1993a). Contested forests: Modern conservation and historical land use of Guinea's Ziama Reserve. Working Paper 7. Kissidougou (Guinea), Connaissance et Organisation Locales Agro-ecologiques (COLA).

Fairhead, J. and Leach, M. (1993b). Degrading people? The misuse of history in Guinea's environmental policy. Paper presented at the African Studies Association meeting, Boston, December 1993.

FAO. (1985). Tree growing by rural people. Forestry Paper No.64. Rome, FAO.

Fisk, E.K. (1975). The response of nonmonetary production units to contact with the exchange economy. In, Agriculture in development theory (ed. Lloyd G. Reynolds), 53-83. New Haven and London, Cass.

Fortmann, L., and Nhira, C. (1992).Local management of trees and woodland resources in Zimbabwe: a tenurial niche approach. OF1 Occasional Paper No.43. Oxford, Oxford Forestry Institute.

Gregersen, H., Oram, P., and Spears, J. (1992). Priorities for forestry and agroforestry policy research: report of an international workshop. Washington, D.C., International Food Policy Research Institute.

Hardcastle, P. (1993). Forestry and tree resources. Working paper prepared for the Malawi National Forest Policy Review. FAO Investment Center.

Jackson, J.C. and Collier, P. (1988). Incomes, Poverty, and Food Security in the Communal Lands of Zimbabwe. Occasional Paper No. 11. Harare, Department of Rural and Urban Planning, University of Zimbabwe.

Kilby, P., and Liedholm, C. (1986). The role of nonfarm activities in the rural economy. Employment and Enterprise Policy Analysis Discussion Papers. Cambridge, Harvard Institute for International Development.

Lawton, R.M. (1982). Natural resources of miombo woodland and recent changes in agricultural and land-use practices. Forest Ecology and Management. 4,287-97.

Matakala, P.W. (1986). Problems of forest extension work in the Zambia teak forests. In, The Zambezi Teak Forests (ed.G.D.Piearce), pp.416-26. Proceedings of the First International Conference on the Teak Forests of Southern Africa, held in Livingstone, Zambia,. March 1984. Ndola, Forest Department of Zambia.

McGregor, J. (199 1). Woodland resources: ecology, policy and ideology. Unpublished PhD thesis. Loughborough, Loughborough University of Technology.

Reed, D. (1992). Structural adjustment and the environment. Boulder, Westview.

Repetto, R., Magrath, W., Wells, M., Beer, C., and Rossini, F. (1989). Wasting assets: Natural resources in the National Income Accounts. Washington, D.C., World Resources Institute. 
Scherr, S. and Vosti, S. (1993). Household data needs for food policy: Toward criteria for choice of approaches. In, Data needs for food policy in developing countries: New directions for household surveys (ed. J.von Braun and D. Puetz), 44-79. Washington, D.C., International Food Policy Research Institute.

Scoones, I. (1989). Patch use by cattle in a dryland environment: Farmer knowledge and ecological theory. In, People, Land and Livestock, Proceedings of a workshop on Socio-economic Dimensions of Livestock Production in the Communal Lands of Zimbabwe, 12-14 September 1988, held at the Center for Applied Social Sciences, University of Zimbabwe, (ed. B. Cousins), 277-310. Harare, Center for Applied Social Sciences.

Scoones, I. (1990). Livestock populations and the household economy: a case study from southern Zimbabwe. Unpublished PhD thesis. London, University of London.

Scoones, I., and Wilson, K. (1989). Households, lineage groups and ecological dynamics: Issues for livestock development in Zimbabwe's communal lands. In, People, Land and Livestock, Proceedings of a workshop on Socio-economic Dimensions of Livestock Production in the Communal Lands of Zimbabwe, 12-14 September 1988, held at the Center for Applied Social Sciences, University of Zimbabwe, (ed. B. Cousins), 17-122. Harare, Center for Applied Social Sciences.

Scoones, I. and Matose, F. (1992). Woodland management in Zimbabwe: Tenure and institutions for sustainable natural resource use. Working paper prepared for the Zimbabwe National Policy Review of Forests and Trees. London and Harare, International Institute for Environment and Development and the Forestry Commission of Zimbabwe.

Solorzano, R, de Camino, R., Woodward, R., Watson, V., Vasquez, A., Villalobos, C., Jimenez, J., Repetto, R, and Cruz, W. (1991). Accounts overdue: Natural resource depletion in Costa Rica. San Jose (Costa Rica) and Washington, D.C., Tropical Science Center and the World Resources Institute.

Tagwireyi, J. (199 1). Food access and nutrition linkages: policy issues and programme options in Zimbabwe. In, Market reforms, research policies and SADCC food security, (ed. M.Rukuni and J.B. Wyckoff), 63-74. Harare, University of Zimbabwe.

Tiffen, M., Mortimore, M, and Gichuki, F. (1994). More people, less erosion: environmental recovery in Kenya. Chichester, Wiley.

van Tongeren, J., Schweinfest, S., Lutz, E., Gomez Luna, M., and Guillen Martin, F. (1991). Integrated environmental and economic accounting: A case study for Mexico. Environment Department Working Paper No.50. Washington, D.C., World Bank.

Wilson, K.B. (1990). Ecological dynamics and human welfare: a case study of population, health and nutrition in southern Zimbabwe. Unpublished $\mathrm{PhD}$ thesis. London, University of London (Department of Anthropology).

Wilson, K.B. (1991). Rainfall variability, ecological change, and population dynamics: a case study from an area of southern Zimbabwe. Paper presented to a conference on "Population and the Environment", London School of Hygiene and Tropical Medicine, 10 January 1991. 